\title{
Cultivation of Rickettsia amblyommii in tick cells, prevalence in Florida lone star ticks (Amblyomma americanum)
}

\author{
Katherine A Sayler ${ }^{1 *}$, Heather L Wamsley ${ }^{1}$, Melanie Pate ${ }^{1}$, Anthony F Barbet ${ }^{2}$ and A Rick Alleman ${ }^{1}$
}

\begin{abstract}
Background: Rickettsia amblyommii is a bacterium in the spotted fever group of organisms associated with the lone star tick (LST), Amblyomma americanum. The LST is the most commonly reported tick to parasitize humans in the southeastern US. Within this geographic region, there have been suspected cases of Rocky Mountain spotted fever (RMSF) where the causative agent, $R$. rickettsii, was not identified in the local tick population. In these areas, patients with clinical signs of RMSF had low or no detectable antibodies to R. rickettsii, resulting in an inability to confirm a diagnosis.

Methods: R. amblyommii was cultivated from host-seeking LSTs trapped in Central Florida and propagated in ISE6 (Ixodes scapularis) and AAE2 (A. americanum) cells. Quantitative PCR targeting the 17-kD gene of Rickettsia spp. identified the genus of the organism in culture. Variable regions of groEL, gt/A and rompA genes were amplified and sequenced to confirm the species. The prevalence of $R$. amblyommii in LSTs within the geographic region was determined by qPCR followed by conventional PCR and direct sequencing.

Results: Analyses of amplified sequences from the cultured organism were 100\% homologous to R. amblyommii. The overall prevalence of Rickettsia spp. in the local population of LSTs was $57.1 \%$ and rompA sequence analysis identified only R. amblyommii in LSTs.

Conclusions: A Florida strain of R. amblyommii was successfully cultivated in two tick cell lines. Further evaluation of the new strain and comparisons to the other geographic strains is needed. The prevalence of this SFG organism in the tick population warrants further investigation into the organism's ability to cause clinical disease in mammalian species.
\end{abstract}

Keywords: Amblyomma americanum, Lone star tick, Rickettsia amblyommii, Tick-borne, Tick cell culture

\section{Background}

Rickettsia amblyommii is an incompletely characterized alphaproteobacterium in the spotted fever group (SFG) of organisms. This organism has been identified in many species of Amblyomma ticks including Amblyomma americanum, Amblyomma maculatum and Amnlyomma cajennense. The preferred tick host in the United States appears to be the lone star tick (LST), A. americanum, and has been identified in $41.2 \%$ [1] to $64.5 \%$ [2] of host-seeking A. americanum collected from diverse geographic regions

\footnotetext{
*Correspondence: saylerk@ufl.edu

'Department of Physiological Sciences, University of Florida College of

Veterinary Medicine, Gainesville, Florida, USA

Full list of author information is available at the end of the article
}

of the United States. The organism was reportedly highly prevalent (89\%) in pools of the immature life stages of $A$. americanum by polymerase chain reaction (PCR) [3] and was detected in $66.5 \%$ to $80.5 \%$ of $A$. americanum pools that were directly parasitizing humans [4]. The pervasiveness of this bacterium in all life stages of the vector and in both host-seeking and partially fed ticks, underscores the possibility that it could be transmitted to a mammalian host, as all life stages of the LST will parasitize large mammals [5].

$A$. americanum is a promiscuous, aggressive feeder long known to be a pest and, more recently, a vector of multiple zoonotic pathogens [6-9]. Rocky Mountain spotted fever (RMSF) is most notably caused by Rickettsia 


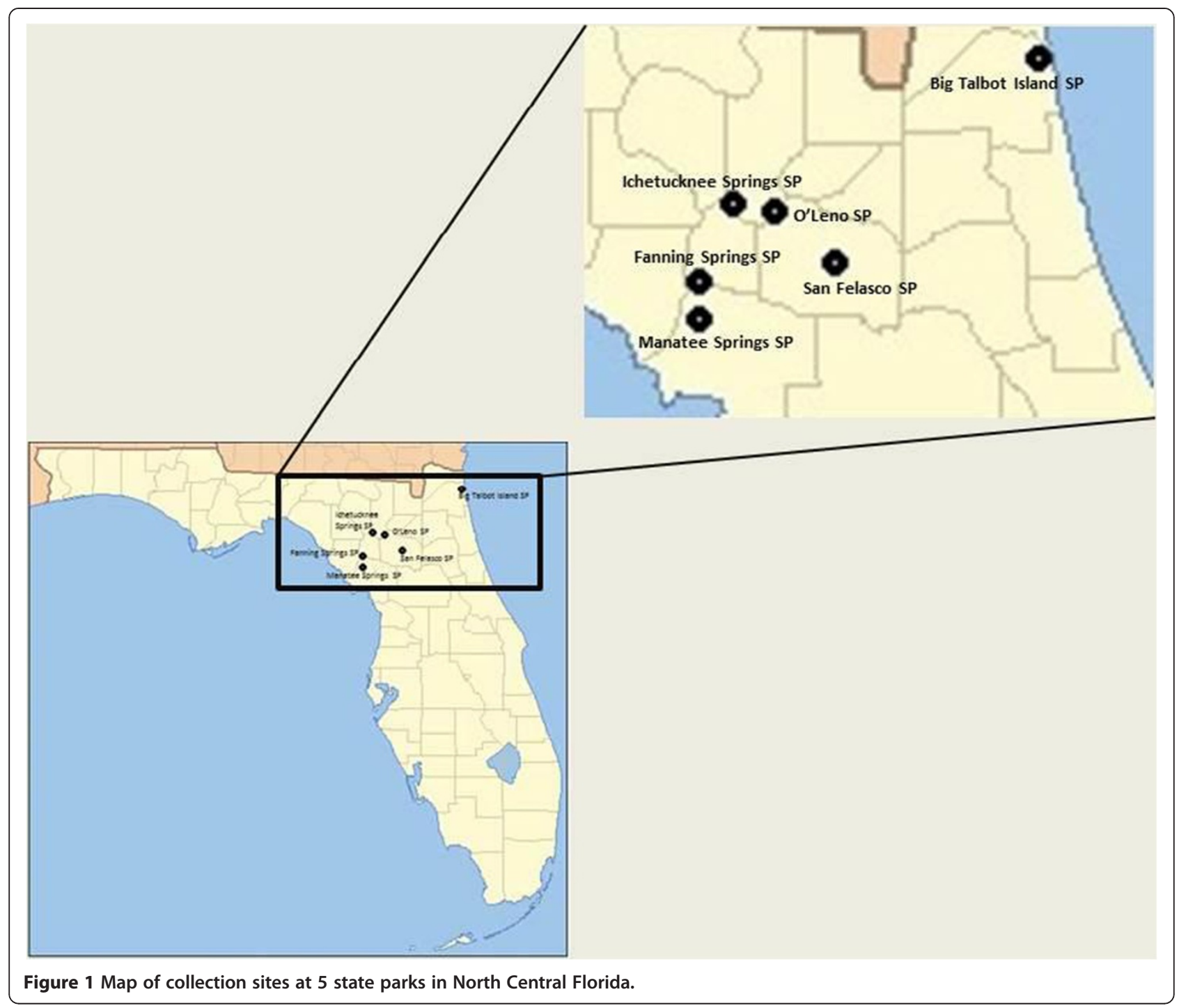

rickettsii, which is primarily transmitted by Dermacentor variabilis and Dermacentor andersoni ticks in the United States. However, R. amblyommii has been implicated as a cause of RMSF-like disease in humans [10] and has been associated with a rash following an $A$. americanum bite [11]. In addition, cases of RMSF are commonly reported in bands across the southeastern United States [12] that correspond to the geographic range of $A$. americanum, even in areas in which Dermacentor variabilis infected with $R$. rickettsii are low in number or absent. This complicates the diagnosis of RMSF in areas where A. americanum is the predominant tick species parasitizing humans $[10,13,14]$. In these areas, it has been suggested that reports of RMSF are more likely due to other Rickettsia spp., such as $R$. amblyommii $[15,16]$. However, due to $R$. amblyommii's symbiont-like pervasiveness and lack of culture isolation from a mammalian species, the importance of this bacterium as a human or animal pathogen is still unclear.

The development of culture systems for the growth of Rickettsia is critical to the genetic and antigenic evaluation of pathogenic and nonpathogenic species, and for comparison of isolates from different geographic regions. It has been shown that growth of tick-borne organisms in different cell lines results in variable expression of important antigens [17]. Because cultured organisms may vary antigenically depending on the culture system used, it would be most beneficial to propagate organisms in cell lines derived from the respective vectors. In the United States, $R$. amblyommii has been propagated in the mosquito Anopheles gambiae cell line [2], and in South America and Central America, African green monkey kidney (Vero) cells have been used to propagate $R$. amblyommii from $A$. cajennense ticks [18]. The growth of $R$. amblyommii in 
Table 12010 LST collection data by Florida state park location

\begin{tabular}{llll}
\hline $\begin{array}{l}\text { State park name } \\
\text { and location }\end{array}$ & $\begin{array}{l}\text { Primary month } \\
\text { of collection }\end{array}$ & $\mathbf{n}$ & $\begin{array}{l}\text { Detectable } \text { R. amblyommii } \\
\text { confirmed by sequencing }\end{array}$ \\
\hline $\begin{array}{l}\text { O'Leno, Columbia } \\
\text { Co. }\end{array}$ & June & 133 & $53(39.8 \%)$ \\
$\begin{array}{l}\text { San Felasco, } \\
\text { Alachua Co. }\end{array}$ & July, August & 53 & $24(45.3 \%)$ \\
$\begin{array}{l}\text { Manatee Springs, } \\
\text { Levy Co. }\end{array}$ & September & 16 & $12(75.0 \%)$ \\
$\begin{array}{l}\text { Ichetucknee, } \\
\text { Columbia Co. }\end{array}$ & July & 5 & $2(40.0 \%)$ \\
& TOTAL: & 207 & $91(44.0 \%)$ \\
\hline
\end{tabular}

The total number of $R$. amblyommii-positive $A$. americanum specimens are given in the final column, with percent infected in parentheses.

a cell line derived from the natural vector, $A$. americanum, could facilitate the generation of large numbers of bacteria for genomic, proteomic, diagnostic, and experimental studies [19]. The development of diagnostic assays specific for $R$. amblyommii infection is needed, as current serology-based methods lack specificity due to cross-reactive antigens within the RMSF group [14].

In this study, A. americanum (AAE2) and Ixodes scapularis (ISE6) cell lines were used to culture $R$. amblyommii from wild $A$. americanum specimens that were trapped in North Central Florida. The prevalence rate of $R$. amblyommii in over 1,400 adult, host-seeking $A$. americanum specimens was also determined using PCR analysis of individually dissected ticks. To our knowledge, this is the first report of successful propagation of $R$. amblyommii in an $A$. americanum tick cell line.

\section{Methods}

\section{Tick collection}

A total of 1,479 host-seeking, unengorged, adult $A$. americanum ticks were collected from six state parks in

Table 22011 LST collection data by Florida state park location

\begin{tabular}{llll}
\hline $\begin{array}{l}\text { State park name } \\
\text { and location }\end{array}$ & $\begin{array}{l}\text { Primary month } \\
\text { of collection }\end{array}$ & $\mathbf{n}$ & $\begin{array}{l}\text { Detectable } \text { R. amblyommii } \\
\text { confirmed by sequencing }\end{array}$ \\
\hline $\begin{array}{l}\text { O'Leno, Columbia } \\
\text { Co. }\end{array}$ & May, June & 391 & $200(51.2 \%)$ \\
$\begin{array}{l}\text { San Felasco, } \\
\text { Alachua Co. }\end{array}$ & June & 472 & $232(49.2 \%)$ \\
$\begin{array}{l}\text { Manatee Springs, } \\
\text { Levy Co. }\end{array}$ & June & 12 & $8(66.7 \%)$ \\
$\begin{array}{l}\text { Fanning Springs, } \\
\text { Gilchrist Co. }\end{array}$ & June & 33 & $21(63.6)$ \\
$\begin{array}{l}\text { Big Talbot Island, } \\
\text { Duval Co. }\end{array}$ & July & 0 & 0 \\
& TOTAL: & 908 & $461(50.8 \%)$ \\
\hline
\end{tabular}

The total number of $R$. amblyommii-positive $A$. americanum specimens are given in the final column, with percent infected in parentheses.
Table 32012 LST collection data by Florida state park location

\begin{tabular}{llll}
\hline $\begin{array}{l}\text { State park name } \\
\text { and location }\end{array}$ & $\begin{array}{l}\text { Primary month } \\
\text { of collection }\end{array}$ & $\mathbf{n}$ & $\begin{array}{l}\text { Detectable } \text { R. amblyommii } \\
\text { confirmed by sequencing }\end{array}$ \\
\hline $\begin{array}{l}\text { O'Leno, Columbia } \\
\text { Co. }\end{array}$ & April, May & 262 & $245(93.5 \%)$ \\
$\begin{array}{l}\text { San Felasco, } \\
\text { Alachua Co. }\end{array}$ & June & $10248(47.1 \%)$ \\
& TOTAL: & $364293(80.5 \%)$ \\
\hline
\end{tabular}

The total number of R. amblyommii-positive A. americanum specimens are given in the final column, with percent infected in parentheses.

North Central Florida (Figure 1), during the months of May through September of 2010 and 2011 and March through August of 2012. At sites where ticks were collected on multiple occasions (O'Leno, San Felasco and Manatee Springs), multiple sites were sampled, typically around wooded areas adjacent to the parking lots, playground equipment, and the main campgrounds of each facility. Ticks were collected according to guidelines of the Florida Department of Environmental Protection research and collection permits \#05201020-A, 06201120 and 06201120, and in agreement with the Florida Division of Recreation and Parks. Briefly, ticks were collected using $\mathrm{CO}_{2}$-emitting dry-ice traps as previously described [20] and by flagging. Flagging was accomplished by dragging a 1 meter $\times 1.5$ meter white linen cloth over areas of high grass and brush. Live ticks were transported in double-sealed containers in designated vehicles to the University of Florida, College of Veterinary Medicine (CVM) for processing. Viable $A$. americanum were identified and sexed according to published guidelines and stored at $4^{\circ} \mathrm{C}$ in the transport containers until prepared for dissection (no more than 4-week storage time). Individual ticks were dissected under aseptic conditions in sterile petri dishes using flame-sterilized scalpels and dissection forceps. Prior to dissection, each tick was washed in $200 \mu \mathrm{L}$ of a $10 \%$ bleach solution for five minutes, followed by three washes in $200 \mu \mathrm{l}$ of $70 \%$ ethanol, vortexed for 15 seconds per wash in a DNA-free SealRite PCR tube (USA Scientific, Ocala, Florida), and then rinsed three times in deionized water to remove residual alcohol. Midguts and salivary glands were removed from each tick and placed singly in $200 \mu \mathrm{l}$ of sterile 1X phosphate buffered saline (Cellgro, Mediatech Inc., Manassas,Virginia). Genomic DNA was extracted from the dissected material using DNeasy Blood and Tissue Kit (Qiagen,Valencia, California) according to the manufacturer's instructions. Tick dissections and gDNA extractions were performed in separate, designated areas of the laboratory to maintain a clean environment and sterile petri dishes, instruments, and filtered tips were used in every step of tick preparation for molecular work. In addition, four pools of $15 \mathrm{~A}$. americanum specimens 
were similarly dissected for immediate inoculation into cell cultures.

\section{PCR}

Real-time PCR targeting a conserved region of the 17$\mathrm{kD}$ antigen gene of Rickettsia spp. was performed using primers R17D135F and R17D249R and a dual-labeled Taqman probe as previously described [21]. Individual DNA samples were tested in MicroAmp Fast Optical 96-well reaction plates (Applied Biosystems, Foster City, California), with $2 \mu \mathrm{L}$ of template DNA in a $20 \mu \mathrm{l}$ final reaction volume. PCR amplification and data analysis were performed using the Prism 7500 thermocycler and associated software (Applied Biosystems, Foster City, California). Brilliant II QPCR Master Mix (Strategene, La Jolla, California) was used for all reactions under the following thermocycler conditions: $95^{\circ} \mathrm{C}$ for 10 minutes, followed by 40 cycles of $95^{\circ} \mathrm{C}$ for 15 seconds and $57^{\circ} \mathrm{C}$ for 60 seconds. To further characterize organisms in Rickettsia-positive ticks, the rompA gene was targeted in a $50 \mu \mathrm{l}$ conventional PCR reaction, as previously described [22]. Amplicons were identified on a $2 \%$ trisacetate-EDTA (TAE) gel by electrophoresis and visualized under UV light using Gelstar nucleic acid gel stain (Lonza, Rockland, Maine). PCR products were purified using QIAquick PCR purification kit (Qiagen, Valencia, California) according to the manufacturer's instructions. Purified amplicons were sequenced at the University of Florida Interdisciplinary Center for Biotechnology Research (ICBR) core laboratory. In both protocols described above, Rickettsia conorii, which was graciously provided by Dr. Jere McBride and Dr. Xuejie Yu (Center for Biodefense and Emerging Infectious Diseases; Sealy Center for Vaccine Development, University of Texas Medical Branch, Galveston, Texas) was used to generate standards and controls for Rickettsia spp. Nucleic acid-free molecular grade water was used as a negative control in all PCR reactions and PCR was performed in a designated area in a laboratory, separate from the area in which culture of organisms took place.

\section{Source and preparation of $R$. amblyommii inocula}

An additional 60 adult, female, host-seeking A. americanum were collected from O'Leno State Park in High Springs, Florida, in June 2012. Live LSTs were transported to the University of Florida CVM in doublesealed containers and stored overnight at $4^{\circ} \mathrm{C}$. The following morning, ticks were washed and dissected under sterile conditions as described above, and pooled into 4 groups of 15 ticks each. Pools were transferred to tubes containing $1 \mathrm{~mL}$ of cold tick cell culture medium L-15B300 [23] supplemented with 20\% fetal bovine serum (FBS) (Sigma, St. Louis, Missouri), and penicillin, streptomycin, and amphotericin B (50 IU/
$\mathrm{mL}, 50 \mu \mathrm{g} / \mathrm{mL}$, and $0.125 \mu \mathrm{g} / \mathrm{mL}$, respectively) (Antimicrobial Solution 17-745, Lonza BioWhittaker, Basel, Switzerland). Preparations were maintained at $4^{\circ} \mathrm{C}$ to maintain organism viability.

\section{Cultivation of $R$. amblyommii in tick cell culture}

Two tick cells lines (Amblyomma americanum, AAE2 and Ixodes scapularis, ISE6) ${ }^{\text {a }}$ were cultivated in T25 flasks as described elsewhere [24]. When cells were confluent, 4 flasks (1 flask containing AAE2, and 3 flasks containing ISE6) were each inoculated with a pooled dissected-tick preparation described above. Immediately after inoculation, the flasks were incubated $\left(25^{\circ} \mathrm{C}\right)$ in a biological safety cabinet for 30 minutes. Subsequently, the flasks were brought to full volume $(7 \mathrm{~mL})$ in L15B300 medium supplemented with FBS, penicillin, streptomycin, and amphotericin $\mathrm{B}$ as described above. Flasks were maintained unvented at $34^{\circ} \mathrm{C}$ with weekly medium changes and passages as needed. The antimicrobial solution was no longer added to the medium after week 4 of cultivation. Flasks were monitored for infection using phase contrast microscopy and WrightGiemsa stained cytocentrifuged preparations of detached cells were examined using light microscopy.

\section{Identification of cultivated organisms}

Infected tick cells were detached from culture flasks using a cell scraper or pipette fluid stream, transferred in medium to a $1.5 \mathrm{~mL}$ microcentrifuge tube and centrifuged at 13,000 rpm for 10 minutes. The cell pellet was resuspended in $100 \mu \mathrm{L}$ of sterile $1 \mathrm{X}$ phosphate buffered saline (PBS). Genomic DNA was isolated from cell cultures using DNeasy Blood and Tissue Kit cell culture protocol (Qiagen, Valencia, California) and gDNA was quantified using fluorometry (Qubit, Invitrogen, Carlsbad, California). A minimum of 150 ng of DNA was screened for the presence of Rickettsia sp., targeting the 17-kD conserved region as outlined above, and species identification was performed using primers that target the rompA gene, as outlined above. Purified amplicons were sequenced and analyzed as described above.

Additional primer sets were also used to confirm the identity of the cultured Rickettsia sp. The groEL gene of SFG Rickettsia sp. was targeted in conventional PCR as previously described [25] slightly modified by employing Taq PCR Master Mix (Qiagen, Valencia, California) under the following conditions: $95^{\circ} \mathrm{C}$ for 3 minutes, followed by 30 cycles of $94^{\circ} \mathrm{C}$ for 30 seconds, $56^{\circ} \mathrm{C}$ for 30 seconds, $72^{\circ} \mathrm{C}$ for 30 seconds, with a $72^{\circ} \mathrm{C}$ final extension for 5 minutes. Additionally, the citrate synthase gene ( $g l t-\mathrm{A})$ was also targeted as previously described [26] using primers CS-78 and CS-323, for specific genetic identification of the infecting rickettsiae. All PCR products of the expected size were visualized, purified, sequenced and analyzed as outlined 


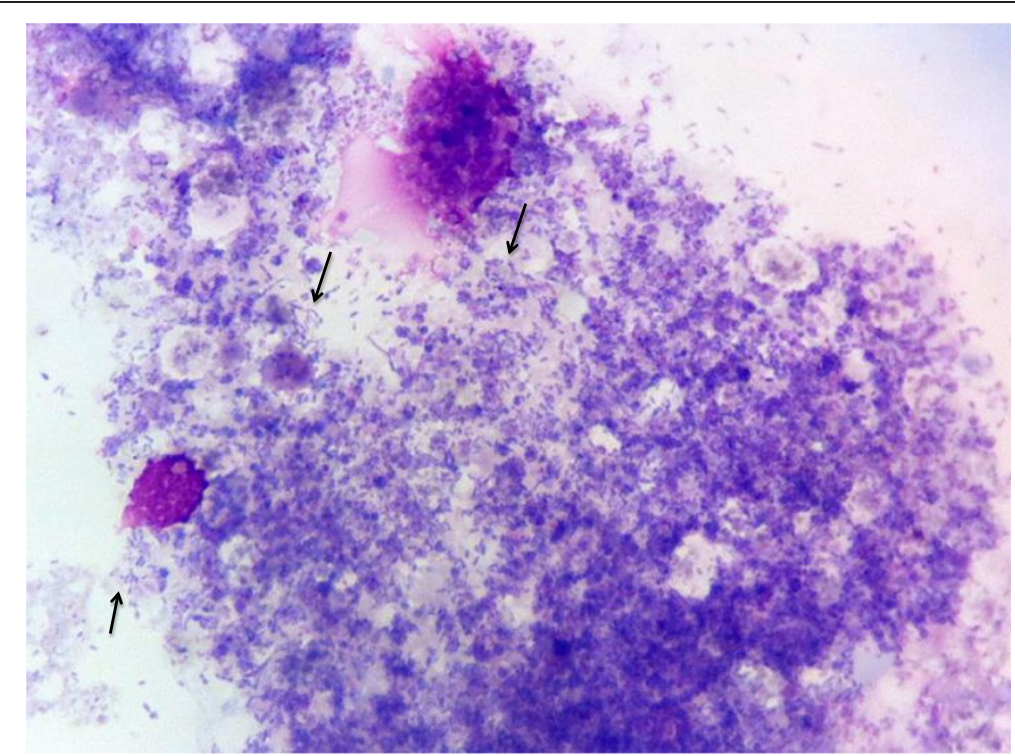

Figure 2 AAE2 cells at 6 weeks post-inoculation. Photomicrograph of cytocentrifugation preparation of infected AAE2 cells. The cells contain abundant, pleomorphic, rod-shaped bacteria (Arrows). (Wright-Giemsa, 100X magnification) Images were captured with Mioticam 580 with 5.0 megapixel (Motic North America, British Columbia, Canada).

above. To confirm that other species of bacteria were not present in culture, the 16s rRNA gene was targeted using bacteria-wide primers, followed by the sequencing of individual clones $(\mathrm{n}=36)$ using the TOPO-4 vector system as previously described [27].

Rickettsial organisms were visualized using light microscopy and photomicrographs were captured using digital photography (Olympus BH2, Olympus, Tokyo, Japan).

\section{Results and discussion Infection survey}

In 2010, a total of 207 unfed adult A. americanum specimens from four counties in central Florida were surveyed (Table 1). The frequency of $R$. amblyommii ranged from $39.8 \%$ to $75 \%$ of individual ticks per state park collection site. Overall, $44.0 \%$ of surveyed ticks carried detectable levels of $R$. amblyommii. In 2011, a total of 908

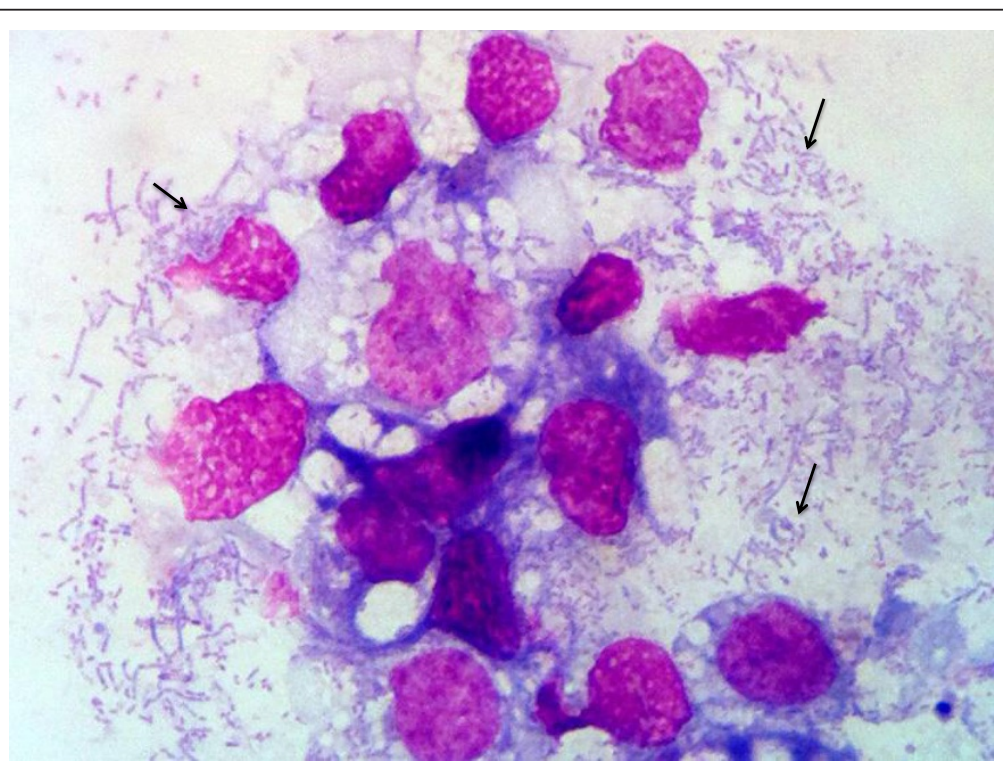

Figure 3 ISE- 6 cells at 6 weeks post inoculation. Photomicrograph of cytocentrifugation preparation of infected ISE- 6 cells. The cells contain abundant, pleomorphic, rod-shaped bacteria (Arrows). (Wright-Giemsa stain, 100X magnification) Images were captured with Mioticam 580 with 5.0 megapixel (Motic North America, British Columbia, Canada). 
unfed, host-seeking $A$. americanum specimens were trapped and screened for the presence of $R$. amblyommii (Table 2). Frequency of the organism ranged from $49.2 \%$ to $66.7 \%$ of individual ticks collected per collection site. Overall, 50.8\% of ticks surveyed in 2011 carried detectable levels of $R$. amblyommii. In 2012, the investigators collected 364 ticks from two parks in which A. americanum populations were highest in 2010, particularly in heavily wooded areas (Table 3). The frequency of $R$. amblyommii ranged from $47.1 \%$ to $93.5 \%$ of the individual ticks by collection site. Overall, $80.5 \%$ of the ticks surveyed in 2012 carried detectable levels of $R$. amblyommii. The average prevalence of Rickettsia in all parks over the three-year collection period was $57.1 \%$ of individual host-seeking LSTs $(845 / 1479)$. This is similar to previously reported prevalence of the organism in LSTs in other geographic areas in the southeastern United States [1]. R. amblyommii was the only Rickettsia spp. detected in all LSTs collected over the three-year period in North Central Florida using the methodology of PCR targeting the rompA gene followed by Sanger sequencing. Our findings are similar to those of other studies that tested for rickettsial infections in the United States in that no other rickettsial species were found in adult host-seeking LSTs $[10,14]$. These data suggest that potential exposure to this organism from the bite of a LST is high. This is of particular concern because all stages of the LST feed on humans, especially adults [3]. Furthermore the tick is expanding its endemic range and increasing its population in established areas, putting people at risk for contacting a potentially infected tick [4].

\section{Isolation and culture of $R$. amblyommii in tick cells}

Rickettsia-specific 17-kD qPCR was performed to monitor culture supernates beginning at approximately 4-weeks post-inoculation. At this time pleomorphic rods typical of SFG rickettsiae were visible in both ISE6 and AAE2 cell lines using Wright-Giemsa-stained cytocentrifugation preparations (Figures 2 and 3). Organisms remained visible by microscopy in both cell lines and remained qPCR-positive through over 20 passages. The cell infection rate remained stable at approximately $85 \%$ of host cells, with many cells rupturing because of the high numbers of rickettsial organisms within them. Amplification of all three Rickettsial genes ( $g l t \mathrm{~A}, d s b$, and rompA) verified that the infecting Rickettsia sp. was Rickettsia amblyommii. Obtained sequences from PCR were identical to those described above. Analysis of rompA clones generated with primers $107 \mathrm{~F}$ and 299R by megaBLAST revealed $98-100 \%$ identity with Candidatus Rickettsia amblyommii strain GAT-30 V (GenBank:NR 074471.1 and GenBank:CP003334.1). No other bacteria species were detected in culture, even when clones were prepared and sequenced from amplicons generated by bacteria-wide primers. Further genetic analysis is needed to compare this new American isolate with the GAT-30 V strain to determine whether regional differences in gene sequences and protein translations might exist.

\section{Conclusions}

The first successful cultivation and propagation of $R$. amblyommii in both Ixodes and Amblyomma tick cell lines and the second isolation of the organism in the United States are reported here. A. americanum is the most common tick infesting people in the central, southern, and southeastern United States, and, as has been shown in previous studies, the majority of adult LSTs are infected with $R$. amblyommii. Attempts to isolate $R$. amblyommii from clinically ill patients and wildlife are ongoing.

\section{Abbreviations}

SFG: Spotted fever group; LST: Lone star tick, common name for Amblyomma americanum.

\section{Competing interests}

The authors declare that they have no competing interests.

\section{Authors' contributions}

KS designed the molecular experiments, participated in field work, performed the tick work, monitored the cultures by PCR and drafted the manuscript; HW designed the culture experiments and assisted in drafting the manuscript; MP maintained the tick cell culture and edited the manuscript; $A B$ assisted in the interpretation of the data and revised the final manuscript; AR participated in field work and assisted in data interpretation. All authors read and approved the final version of the manuscript.

\section{Acknowledgements}

This work was supported by the USDA-TSTAR grant, 2010-34135-21053. Uninfected tick cell cultures were kindly provided by Dr. Uli Munderloh, University of Minnesota.

\section{Author details}

${ }^{1}$ Department of Physiological Sciences, University of Florida College of Veterinary Medicine, Gainesville, Florida, USA. ${ }^{2}$ Department of Infectious Diseases and Pathology, University of Florida College of Veterinary Medicine, Gainesville, Florida, USA.

Received: 15 January 2014 Accepted: 27 May 2014

Published: 13 June 2014

\section{References}

1. Mixson TR, Campbell SR, Gill JS, Ginsberg HS, Reichard MV, Schulze TL, Dasch GA: Prevalence of Ehrlichia, Borrelia, and Rickettsial agents in Amblyomma americanum (Acari: Ixodidae) collected from nine states. $J$ Med Entomol 2006, 43(6):1261-1268.

2. Zhang X, Ren X, Norris DE, Rasgon JL: Distribution and infection frequency of 'Candidatus Rickettsia amblyommii' in Maryland populations of the lone star tick (Amblyomma americanum) and culture in an Anopheles gambiae mosquito cell line. Ticks and Tick-borne diseases 2012, 3(1):38-42.

3. Stromdahl EY, Vince MA, Billingsley PM, Dobbs NA, Williamson PC: Rickettsia amblyommii infecting Amblyomma americanum larvae. Vector borne and Zoonotic diseases (Larchmont, NY) 2008, 8(1):15-24.

4. Jiang J, Yarina T, Miller MK, Stromdahl EY, Richards AL: Molecular detection of Rickettsia amblyommii in Amblyomma americanum parasitizing humans. Vector borne and Zoonotic diseases (Larchmont, NY) 2010, 10(4):329-340.

5. Childs JE, Paddock CD: The ascendancy of Amblyomma americanum as a vector of pathogens affecting humans in the United States. Annu Rev Entomol 2003, 48:307-337. 
6. Anderson BE, Dawson JE, Jones DC, Wilson KH: Ehrlichia chaffeensis, a new species associated with human ehrlichiosis. Journal of Clin Micro 1991 29(12):2838-2842.

7. Everett ED, Evans KA, Henry RB, McDonald G: Human ehrlichiosis in adults after tick exposure: diagnosis using polymerase chain reaction. Ann Intern Med 1994, 120(9):730-735

8. Felz MW, Durden LA, Oliver JH Jr: Ticks parasitizing humans in Georgia and South Carolina. J Parasitol 1996, 82(3):505-508.

9. Savage HM, Godsey MS Jr, Lambert A, Panella NA, Burkhalter KL, Harmon JR, Lash RR, Ashley DC, Nicholson WL: First detection of heartland virus (Bunyaviridae: Phlebovirus) from field collected arthropods. AmJTrop Med Hyg 2013, 89(3):445-452.

10. Apperson CS, Engber B, Nicholson WL, Mead DG, Engel J, Yabsley MJ, Dail K, Johnson J, Watson DW: Tick-borne diseases in North Carolina: is "Rickettsia amblyommii" a possible cause of rickettsiosis reported as Rocky Mountain spotted fever? Vector borne and Zoonotic Diseases 2008, 8(5):597-606.

11. Billeter SA, Blanton HL, Little SE, Levy MG, Breitschwerdt EB: Detection of Rickettsia amblyommii in association with a tick bite rash. Vector borne and Zoonotic Diseases 2007, 7(4):607-610.

12. Chapman AS, Murphy SM, Demma LJ, Holman RC, Curns AT, McQuiston JH, Krebs JW, Swerdlow DL: Rocky mountain spotted fever in the United States, 1997-2002. Ann N Y Acad Sci 2006, 1078:154-155.

13. Fritzen CM, Huang J, Westby K, Freye JD, Dunlap B, Yabsley MJ, Schardein M, Dunn JR, Jones TF, Moncayo AC: Infection prevalences of common tick-borne pathogens in adult lone star ticks (Amblyomma americanum) and American dog ticks (Dermacentor variabilis) in Kentucky. AmJTrop Med Hyg 2011, 85(4):718-723.

14. Moncayo AC, Cohen SB, Fritzen CM, Huang E, Yabsley MJ, Freye JD, Dunlap BG, Huang J, Mead DG, Jones TF, Dunn JR: Absence of Rickettsia rickettsii and occurrence of other spotted fever group rickettsiae in ticks from Tennessee. AmJTrop Med Hyg 2010, 83(3):653-657.

15. McQuiston JH, Zemtsova G, Perniciaro J, Hutson M, Singleton J, Nicholson WL, Levin ML: Afebrile spotted fever group Rickettsia infection after a bite from a Dermacentor variabilis tick infected with Rickettsia montanensis. Vector Borne and Zoonotic Diseases (Larchmont, NY) 2012, 12(12):1059-1061.

16. Paddock CD, Finley RW, Wright CS, Robinson HN, Schrodt BJ, Lane CC, Ekenna O, Blass MA, Tamminga CL, Ohl CA, McLellan SL, Goddard J, Holman RC, Openshaw JJ, Summer JW, Zaki SR, Eremeeva ME: Rickettsia parkeri rickettsiosis and its clinical distinction from Rocky Mountain spotted fever. Clin Infect Dis 2008, 47(9):1188-1196.

17. Ganta RR, Cheng C, Miller EC, McGuire BL, Peddireddi L, Sirigireddy KR, Chapes SK: Differential clearance and immune responses to tick cell-derived versus macrophage culture-derived Ehrlichia chaffeensis in mice. Infect Immun 2007, 75(1):135-145.

18. Labruna MB, Whitworth T, Bouyer DH, McBride J, Camargo LM, Camargo EP, Popov V, Walker DH: Rickettsia bellii and Rickettsia amblyommii in Amblyomma ticks from the State of Rondonia, Western Amazon. Brazil Journal of Medical Entomology 2004, 41(6):1073-1081.

19. Sakamoto JM, Azad AF: Propagation of arthropod-borne Rickettsia spp. in two mosquito cell lines. Appl Environ Microbio/ 2007, 73(20):6637-6643.

20. Ginsberg HS, Ewing CP: Comparison of flagging, walking, trapping, and collecting from hosts as sampling methods for northern deer ticks, Ixodes dammini, and lone-star ticks, Amblyomma americanum (Acari:Ixodidae). Experimental \& Applied Acarology 1989, 7(4):313-322

21. Loftis AD, Reeves WK, Szumlas DE, Abbassy MM, Helmy IM, Moriarity JR, Dasch GA: Surveillance of Egyptian fleas for agents of public health significance: Anaplasma, Bartonella, Coxiella, Ehrlichia, Rickettsia, and Yersinia pestis. AmJTrop Med Hyg 2006, 75(1):41-48.

22. Kidd L, Maggi R, Diniz PP, Hegarty B, Tucker M, Breitschwerdt E: Evaluation of conventional and real-time PCR assays for detection and differentiation of spotted fever group Rickettsia in dog blood. Vet Microbio/ 2008, 129(3-4):294-303.

23. Kurtti TJ, Simser JA, Baldridge GD, Palmer AT, Munderloh UG: Factors influencing in vitro infectivity and growth of Rickettsia peacockii (Rickettsiales: Rickettsiaceae), an endosymbiont of the rocky mountain wood tick, Dermacentor andersoni (Acari, Ixodidae). J Invertebr Pathol 2005, 90(3):177-186.
24. Munderloh UG, Liu Y, Wang M, Chen C, Kurtti TJ: Establishment, maintenance and description of cell lines from the tick Ixodes scapularis. J Parasitol 1994, 80(4):533-543.

25. Lee JH, Park HS, Jang WJ, Koh SE, Kim JM, Shim SK, Park MY, Kim YW, Kim BJ, Kook YH, Park KH, Lee SH: Differentiation of rickettsiae by groEL gene analysis. J Clin Microbiol 2003, 41(7):2952-2960.

26. Labruna MB, McBride JW, Bouyer DH, Camargo LM, Camargo EP, Walker DH: Molecular evidence for a spotted fever group Rickettsia species in the tick Amblyomma longirostre in Brazil. J Med Entomol 2004, 41(3):533-537.

27. Heise SR, Elshahed MS, Little SE: Bacterial diversity in Amblyomma americanum (Acari: Ixodidae) with a focus on members of the genus Rickettsia. J Med Entomol 2010, 47(2):258-268.

\section{doi:10.1186/1756-3305-7-270}

Cite this article as: Sayler et al:: Cultivation of Rickettsia amblyommii in tick cells, prevalence in Florida lone star ticks (Amblyomma americanum). Parasites \& Vectors 2014 7:270.

\section{Submit your next manuscript to BioMed Central and take full advantage of:}

- Convenient online submission

- Thorough peer review

- No space constraints or color figure charges

- Immediate publication on acceptance

- Inclusion in PubMed, CAS, Scopus and Google Scholar

- Research which is freely available for redistribution 